\title{
Traditional Courtyards as a Microclimate in the Improvement of Human Thermal Comfort Condition
}

\author{
Saeid Teshnehdel ${ }^{1, *}$, Mohammadreza Bahari ${ }^{2}$, Seyedasghar Mirnezami $^{3}$ \\ ${ }^{1}$ Department of Architecture, University of Mohaghegh Ardabili, Ardabil, Iran \\ ${ }^{2}$ Department of Architecture, Azad University of Tabriz, Tabriz, Iran \\ ${ }^{3}$ Department of Architecture, Faculty of Architecture, Gazi University, Ankara, Turkey \\ Email address: \\ saeed.te1988@gmail.com (S. Teshnehdel), baharimohammad7777777@gmail.com (M. Bahari), s.asghar.mn@gmail.com (S. Mirnezami) \\ ${ }^{*}$ Corresponding author
}

\section{To cite this article:}

Saeid Teshnehdel, Mohammadreza Bahari, Seyedasghar Mirnezami. Traditional Courtyards as a Microclimate in the Improvement of Human Thermal Comfort Condition. Landscape Architecture and Regional Planning. Vol. 4, No. 3, 2019, pp. 53-60.

doi: $10.11648 /$ j.larp.20190403.12

Received: September 19, 2019; Accepted: October 11, 2019; Published: November 11, 2019

\begin{abstract}
According to population growth, urban sprawl, as well as global warming, attention to the impact of design on thermal comfort in open spaces is important. Thus, it is essential to climate studies and understanding environmental features, as well as results usage in improving designs. The courtyard as open space in residential buildings which is an important factor in the absorption of sunlit in the courtyard surfaces. Therefore, controlling shading performance with regard to thermal comfort condition is one of the most effective factors in reducing the ambient temperature during hot days. This paper focuses on the impact of shading performance in traditional courtyard houses in the hot (Kashan) and cold (Ardabil) climate of Iran. For better understanding four traditional courtyard houses of Kashan and Ardabil selected randomly. By Design Builder software shaded areas were analyzed for each case. The results showed that the best form for the courtyard in these climates is rectangular. The results indicate that increasing the ratio of length to width and also increasing the height of the walls of the courtyard increases the percentage of shading. As conclusion during a day, there is a high correlation between the MRT and the PMV index, and reducing the MRT improve the PMV index.
\end{abstract}

Keywords: Shadows, Sunlit, Thermal Comfort, Microclimate, Traditional Courtyard

\section{Introduction}

Global warming and the associate climate changes are serious issues at planetary level, as observed and predicted since many years [1]. Today, construction demand $34 \%$ of the energy in the world, which is even more than transportation and industrial energy needs, they also represent the biggest potential for producing significant greenhouse gases emission decline at the least cost [2]. Therefore, buildings are responsible for the largest portion of greenhouse emission; having the largest impact on man-made climate change [3]. Issues like thermal comfort, energy saving and controlling the energy exchange between humans, the artificial and natural environments are an integral part of the urban design studies. Therefore, access to sustainable environment for more presence of human in open space should improve the quality of open spaces and human thermal comfort [4]. Thermal comfort is that condition of mind which express satisfaction with thermal environment [5]. The thermal comfort stresses are defined over 10 scales ranging from extreme heat stress to extreme cold stress. The thermal comfort zone is believed to be between $\left(-0.5_{-}+0.5\right)$ for PMV (Table 1) [6].

Table 1. Categorization of PMV and PET level for different thermal sensation and physiological stress [6].

\begin{tabular}{lll}
\hline PMV & Thermal sensation & Grade of Physiological stress \\
\hline Below -3.5 & & \\
-3.5 & Very cold & Extreme cold stress \\
-2.5 & Cold & Strong cold stress \\
-1.5 & Cool & Moderate cold stress \\
-0.5 & Slightly cold & Slight cold stress \\
0.5 & Comfortable & Neutral \\
1.5 & Slightly warm & Slight heat stress \\
\hline
\end{tabular}




\begin{tabular}{lll}
\hline PMV & Thermal sensation & Grade of Physiological stress \\
\hline 2.5 & Warm & Moderate heat stress \\
3.5 & Hot & Strong heat stress \\
Above +3.5 & Very hot & Extreme heat stress \\
\hline
\end{tabular}

One of the most successful samples of climatic responsive architecture is traditional courtyard houses which is the most important factor affecting the absorption of solar energy and controlling the amount of shading. courtyard houses as a the most successful samples of climatic responsive architecture. This research focuses on the environmental aspect of sustainability, with the goal of assessing shading performance of courtyard as a passive cooling/heating technique, to enhance indoor thermal comfort of courtyard houses.

Few literatures also highlighted that the thermal condition inside courtyards is highly dependent on the amount of shading. For instance, Muhaisen [7] emphasized the impact of the climatic variables on the proposed courtyard ratios and heights to reach an appropriate annual performance in four various cities such as Kuala Lumpur, Cairo, Rome and Stockholm, with different climates including hot humid, hot dry, temperate and cold climates, respectively. Their results illustrated that the shading condition of the courtyard inner envelope is effectively dependent on the form's dimensions, proportions, latitude and available climatic features [8]. Soflaei et al. [2] worked on the impact of courtyard design variants on shading performance in hot-arid climates of Iran. They conducted a numerical investigation to determine shaded and sunlit areas of courtyards to find out correlation between geometrical properties and orientation with comfort temperature. Their results show that the courtyard's design variants have considerable influence on the shading performance of courtyards and consequently on residents' thermal comfort. Hassan [9] investigated the potential of a ventilated courtyard for passive cooling in a small building in a hot desert climate in New Aswan City, Egypt. The results show that the courtyard orientation and the courtyard geometry are among the most significant factors, which affect the thermal performance of the courtyard building model. Manioglua and Orala [10], explained that the geometry of the courtyard form (shape) affects considerably the shadows produced on the building envelope, and consequently the received solar radiation and the cooling and heating loads in hot-dry climate. They defined courtyard's shape based on the shape factor $(\mathrm{W} / \mathrm{L})$; the ratio of courtyard width $(\mathrm{W})$ to courtyard length $(\mathrm{L})$. They also examined the variation of the obtained heating and cooling loads as a result of changing the building form with the proportion of the courtyard. Ahmad et al. [11] studied a traditional courtyard house within a six centuries old indigenous urban cluster and compared it to a modern detached house within a new urban development under summer and winter climates of Ghadames, Libya. They showed the thermal comfort superiority of an indigenous courtyard house over a modern pavilion-type house.

This research focuses on the environmental aspect of sustainability, with the goal of assessing shading performance of courtyard as a passive cooling/heating technique, to enhance indoor thermal comfort of courtyard houses.

\section{Methods}

\subsection{Study Area}

The city of Kashan is located at 33 degrees 59 minutes' north latitude and 51 degrees 27 minutes' east longitude at an altitude of 982 meters above sea level. The city has hot, hot summers and cold winters. Average annual temperature is $26^{\circ} \mathrm{C}$, the minimum average annual temperature is $12^{\circ} \mathrm{C}$, and the maximum average annual temperature is $19.8^{\circ} \mathrm{C}$. Ardebil is located at 38 degrees 15 minutes' north latitude and 48 degrees and 17 minutes' east longitude at an altitude of 1332 meters above sea level. It has a very cool winter and suitable summer. The average annual temperature is $9.2^{\circ} \mathrm{C}$, the average minimum annual temperature is $3^{\circ} \mathrm{C}$, and the average maximum annual temperature is $15.5^{\circ} \mathrm{C}$. In the winter, the air is so cold that even in the warmest sunny days, the thermal conditions of the sunshine are also very cold, but in the summer, the air is so convenient that even in the warmest hours, the exterior spaces in the shade, have a good thermal condition Have a comfortable look at humans. Tables 2 and 3 show the average monthly and maximum monthly temperatures of the cities of Kashan and Ardabil [12].

Table 2. Minimum and maximum of monthly average temperature of Kashan and Ardabil cities in December and June.

\begin{tabular}{|c|c|c|c|c|c|c|c|c|c|c|c|c|c|}
\hline & & Jan & Feb & Mar & Apr & May & Jun & Jul & Aug & Sep & Oct & Nov & Dec \\
\hline \multirow{3}{*}{$\begin{array}{l}\text { Kashan } \\
(1966-2005)\end{array}$} & Min & -0.3 & 1.5 & 6.3 & 12.1 & 16.9 & 21.9 & 24.8 & 23.3 & 18.4 & 12 & 6.2 & 1.5 \\
\hline & Max & 10.2 & 13.4 & 19 & 26.3 & 31.8 & 38.2 & 40.8 & 39.9 & 35.3 & 27.6 & 18.9 & 12.1 \\
\hline & Average & 5 & 7.7 & 13.2 & 20 & 25.4 & 31.4 & 34 & 32.6 & 27.8 & 20.6 & 12.8 & 6.8 \\
\hline \multirow{3}{*}{$\begin{array}{l}\text { Ardabil } \\
(1977-2005)\end{array}$} & Min & -7.8 & -5.8 & -2 & 2.9 & 6.2 & 9.2 & 11.7 & 11.7 & 8.9 & 5.1 & 0.3 & -4.5 \\
\hline & Max & 3 & 4.9 & 9.8 & 16.6 & 19.9 & 23.4 & 25.1 & 25.1 & 22.7 & 17.7 & 11.6 & 5.9 \\
\hline & Average & -2.4 & -0.5 & 3.9 & 9.7 & 13.1 & 16.3 & 18.4 & 18.4 & 15.8 & 11.4 & 5.9 & 0.7 \\
\hline
\end{tabular}

Table 3. 3 hours average temperature of Kashan and Ardabil cities in December and June.

\begin{tabular}{|c|c|c|c|c|c|c|c|c|c|}
\hline & Time & 0:00 & $3: 00$ & $6: 00$ & 9:00 & 12:00 & 15:00 & 18:00 & 21:00 \\
\hline \multirow{2}{*}{ Kashan } & 22-Dec & 1.97 & 2.96 & 5.27 & 9.55 & 11.3 & 7.94 & 5.28 & 3.35 \\
\hline & 22-Jun & 28.6 & 27.2 & 33.3 & 37.8 & 40.6 & 39.36 & 34.9 & 31.7 \\
\hline \multirow{2}{*}{ Ardabil } & 22-Dec & -0.97 & -1.6 & 1.11 & 3.64 & 4.2 & 1.08 & 0.25 & -0.64 \\
\hline & 22-Jun & 14.02 & 14.7 & 21.47 & 24.95 & 24.62 & 21.02 & 17.9 & 16.2 \\
\hline
\end{tabular}




\subsection{Model Simulation}

The Designbuilder software is utilized to calculate the shading performance and thermal condition. It should be noted that in these analyses, all parameters of temperature, sunlit, humidity and wind speed were considered. The output of these simulations was the shading and sunlit percentage of floors and walls and PMV index.

\subsection{Validation}

In order to validate the numerical model a physical measurement was conducted on shading performance of $\mathrm{Al} \mathrm{e}$ Yasin courtyard house in Kashan, Iran.

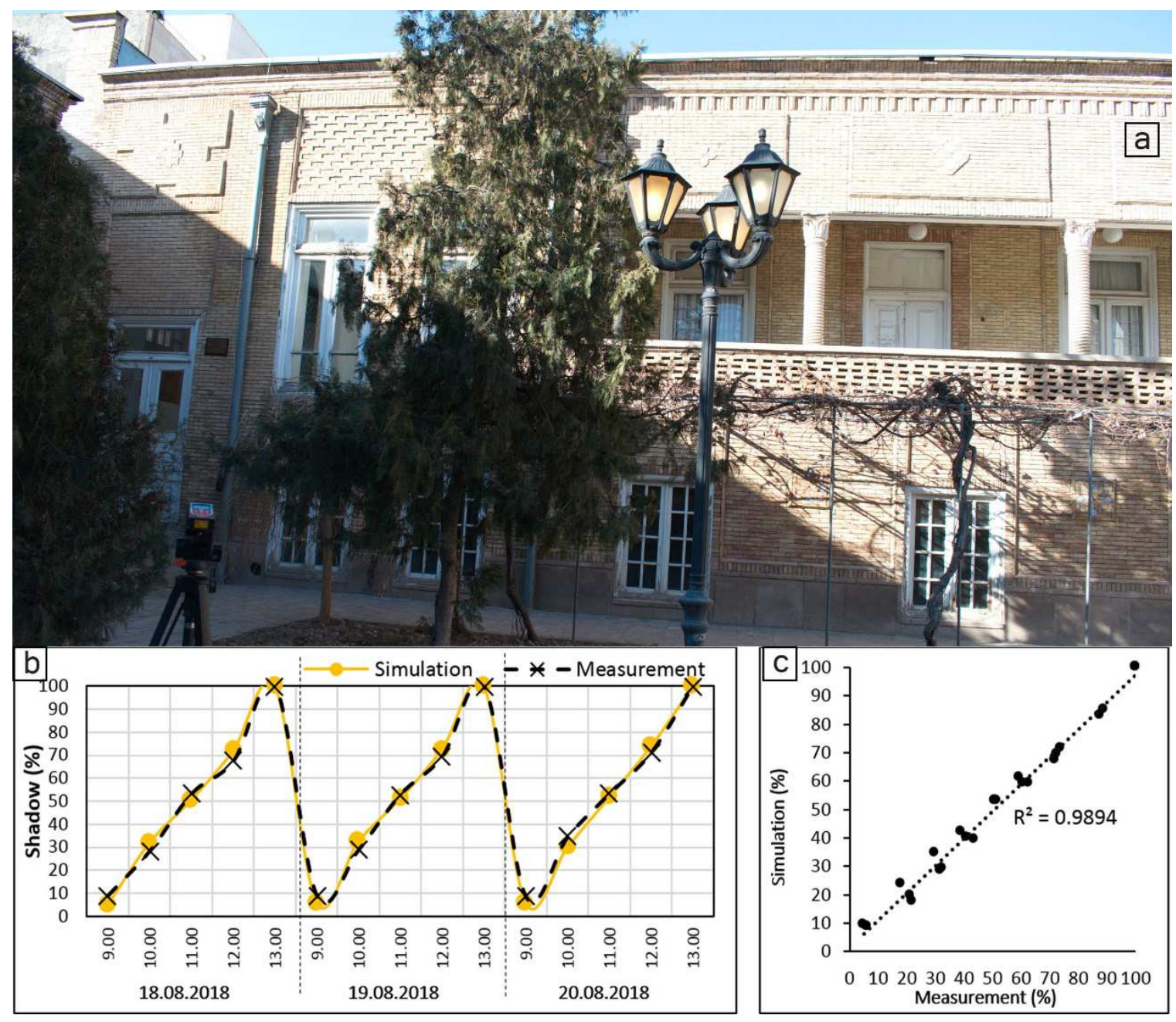

Figure 1. Measurement was carried out on shading area by laser distance meter on the western façade of Borujerdi courtyard house in Kashan, Iran (a). Comparison of the shade percentage between simulation results and the measurements on 18, 19 and 20 August (b). The comparison of the shade percentage in a scattered graph $(c)$.

The measuring instruments is placed $1.5 \mathrm{~m}$ above ground with time interval of 60 minutes is used to measure the drybulb temperature, relative humidity and measurement was carried out on shading area on the western façade of this house. A field survey was conducted for three consecutive days on 18, 19 and 20 August. Then the measured data were averaged over these three days and compared with the simulated averaging data. Figure 1 demonstrates a comparison of both the simulation and obtained data of measurements. This comparison verifies the conducted simulation. Based on the results obtained, the correlation between the measured data and simulation on shading is 0.98 which indicates high consistency. (Figure 1).

Table 4 illustrate all simulation and measurement results.

Table 4. Different results between the measured and simulation data.

\begin{tabular}{lllllll}
\hline Time & Shadow (\%) & & \multicolumn{2}{l}{ Temperature $\left({ }^{\circ} \mathbf{C}\right)$} & Humidity $(\%)$ \\
\cline { 2 - 6 }$(\mathbf{0 8 . 1 8 . 2 0 1 8})$ & Simulation & Measurement & Simulation & Measurement & Simulation & Measurement \\
\hline $09: 00$ & 5.04 & 9.07 & 26.9 & 27.6 & 26 \\
$10: 00$ & 32.11 & 28.4 & 28.7 & 29 & 25 \\
$11: 00$ & 50.76 & 53.24 & 30.3 & 29.7 & 24 & 24 \\
\hline
\end{tabular}




\begin{tabular}{lllllll}
\hline Time & Shadow $(\%)$ & & Temperature $\left({ }^{\circ} \mathbf{C}\right)$ & Humidity $(\%)$ \\
$\mathbf{( 0 8 . 1 8 . 2 0 1 8})$ & Simulation & Measurement & Simulation & Measurement & Simulation & Measurement \\
\hline 12:00 & 72.14 & 67.41 & 32.2 & 31.8 & 24 & 23 \\
13:00 & 100 & 100 & 33.1 & 32.6 & 22 & 21 \\
$14: 00$ & - & - & 33.6 & 32.8 & 21 & 20 \\
$15: 00$ & - & - & 34.2 & 33.5 & 19 & 19 \\
$16: 00$ & - & - & 34.6 & 33.6 & 17 & 16 \\
\hline
\end{tabular}

\section{Result and Discussion}

The quality of urban environments has recently become a multidisciplinary subject [13-16]. In fact, the meteorologists gradually shifted their focus on visible changes of urban climates and heat islands to micro scales $[17,18]$. One of the influential factors in the architecture of Kashan and Ardabil houses is the climatic characteristics of its site. The architectural differences in the warm and cold regions reveal the fact that "this architecture, with the help of the tools and techniques devised in history, has been adapted to the delusions and climatic problems of the region, and by creating an environment suitable for human life, the possibility of peaceful coexistence. some studies by the factors of microclimatic parameters have evaluated thermal comfort condition. The influence of these parameters can be also assessed by adjustment of the courtyard's geometrical and orientation to provide maximum indoor thermal comfort [19-21]. The interconnectedness between $\operatorname{man}$ and his environment has provided" [22]. Cho and Mohammadzadeh
[23] conducted comprehensive study on thermal comfort analysis of traditional courtyards in Iran by using Energy Plus software program. It examined the interaction taking place between the sun at any time throughout the year and a circular courtyard form with any dimensions and proportions in any place on the earth. Their results showed that changing the form's proportions significantly influences the shading or exposure potential of the internal courtyard envelope [24]. Muhaisen and Gadi [25], also examined the shading performance of polygonal courtyard forms with pentagonal, hexagonal, heptagonal and octagonal plans. As you know, heat is the main problem of Kashan's climate, and its best solution is to control sunlight and create a shadow during hot weather on the walls of buildings, which requires 9-10 months of the year (July 2008). While cold the main problem in the climate of Ardebil and the most beneficial solution is the use of sunlight on the outer walls of buildings during cold weather, which is felt to be shady in this climate for 3-4 months from the year. Physical characteristics of the species studied in Kashan and Ardebil shows on table 5.

Table 5. Physical characteristics of the species studied in Kashan and Ardebil.

\begin{tabular}{llllll}
\hline & Kashan Houses & & & & \\
\hline
\end{tabular}

For better understanding, tables 6 and 7 show the percentage of shading for vertical and horizontal surfaces in Ardebil and Kashan courtyards at $12 \mathrm{pm}$ in the first day of July and January. 
Table 6. The percentage and percentage of shading houses in Kashan on July 1, at 12:00.

\begin{tabular}{llllllll}
\hline Date & Esfahanian & & Taghavi \\
\hline & & & & & & & \\
\end{tabular}

Table 7. The percentage and percentage of shadowing of Kashan's homes in the first day of December, $12^{\text {th }}$.

\begin{tabular}{|c|c|c|c|c|c|c|c|c|}
\hline Date & Esfahanian & \multirow{3}{*}{\multicolumn{2}{|c|}{$\begin{array}{l}\text { Shadow Area } \\
\left(\mathrm{m}^{2}\right)\end{array}$}} & & \multirow{3}{*}{$\begin{array}{l}\text { Ershadi } \\
\begin{array}{l}\text { Shadow Area } \\
\left(\mathbf{m}^{2}\right)\end{array}\end{array}$} & \multirow[b]{3}{*}{$\begin{array}{l}\text { Shadow } \\
(\%)\end{array}$} & \multicolumn{2}{|l|}{ Taghavi } \\
\hline \multirow[t]{2}{*}{$\begin{array}{l}\text { January } 1 \\
(12: 00)\end{array}$} & & & & & & & & \\
\hline & $\begin{array}{l}\text { Shadow Area } \\
\left(\mathrm{m}^{2}\right)\end{array}$ & & & $\begin{array}{l}\text { Shadow } \\
(\%)\end{array}$ & & & $\begin{array}{l}\text { Shadow Area } \\
\left(\mathrm{m}^{2}\right)\end{array}$ & $\begin{array}{l}\text { Shadow } \\
\text { (\%) }\end{array}$ \\
\hline courtyard & 456.26 & 61.05 & 45.05 & 73.06 & 45.05 & 73.06 & 193.84 & 82.72 \\
\hline Wall 1 & 304.15 & 66.47 & 15.29 & 55.39 & 15.29 & 55.39 & 47.51 & 28.28 \\
\hline Wall 2 & 385.75 & 100 & 33.15 & 100 & 33.15 & 100 & 204.62 & 67.11 \\
\hline Wall 3 & 353.62 & 100 & 27.27 & 100 & 27.27 & 100 & 164.54 & 100 \\
\hline Wall 4 & 350.98 & 100 & 10.37 & 21.56 & 10.37 & 21.56 & 205.51 & 100 \\
\hline Total & 1850.76 & 80.6 & 131.1 & 66.3 & 131.1 & 66.3 & 816.02 & 75.8 \\
\hline
\end{tabular}

Figure 2 show the average shade coverage of the yard walls on the first day of July and January in both climates.

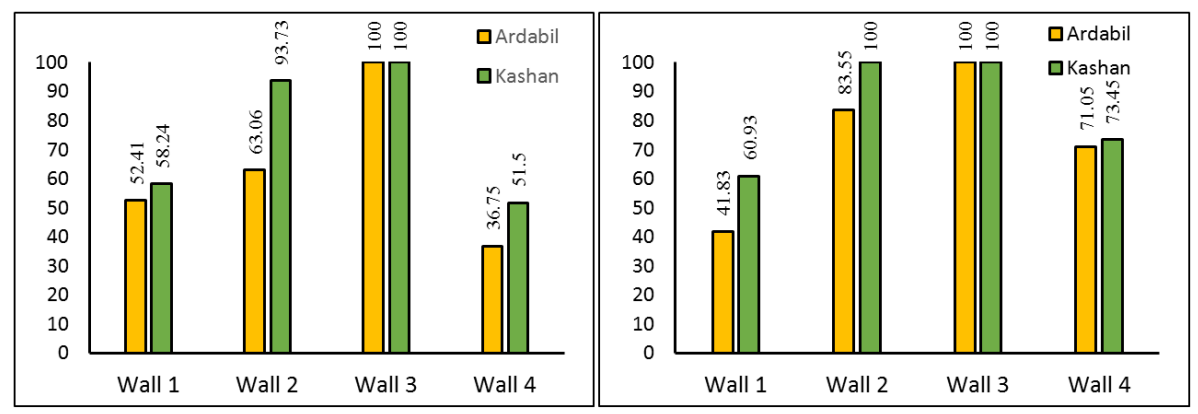

Figure 2. Shadow percentage in 1 July (Right). Shadow percentage in 1 January (Left).

In order to better study the difference between the amounts of shading in the samples of Kashan climate with Ardebil climate, the average shadow in each wall was calculated and measured by season and time. As shown in the graphs, there are differences between the shadow created in Kashan samples and samples of Ardabil in different levels. According to Chart 1 , the average shade cover ratio of 1 to 4 in the homes of Kashan is 58.24, 93.73, 100 and 51.5\% on the first of July. Also, the average percentage of shadow in Ardebil houses is $52.14 \%, 63.66 \%, 100 \%$ and $35.36 \%$ respectively on the first of July. In all studied houses, the maximum amount of summer shade for wall 3 and the lowest amount of shade cover for wall 4 . The percentage of cover shadow covering 1 to 4 in Kashan samples related to the first day of the month is $60.93,100,100$ and 73.45 , respectively. The average shade cover in Kashan samples was $41.83 \%$, $83.55 \%, \quad 100 \%$ and $71.5 \%$ respectively. Therefore, considering the hot climate of Kashan and the cold climate of Ardebil, the studied houses of Kashan and Ardebil The view of the shadow coating is appropriate for warming the climate in the region, but in terms of solar radiation, it does not fit well with the climate of the region during the cold months of 
the year.

With regard to Figure 3, The PMV distribution analysis are only considered at 6 am to $9 \mathrm{pm}$, since there are many models and Figure which describe the PMV distribution. This time frame is chosen for analysis purposes of PMV distribution rate, since 6 am and $15 \mathrm{pm}$ are the most uncomfortable periods to use the courtyards. The simulated results of models at 10 am and $18 \mathrm{pm}$ are shown in Figure 4 below are comfortable time.
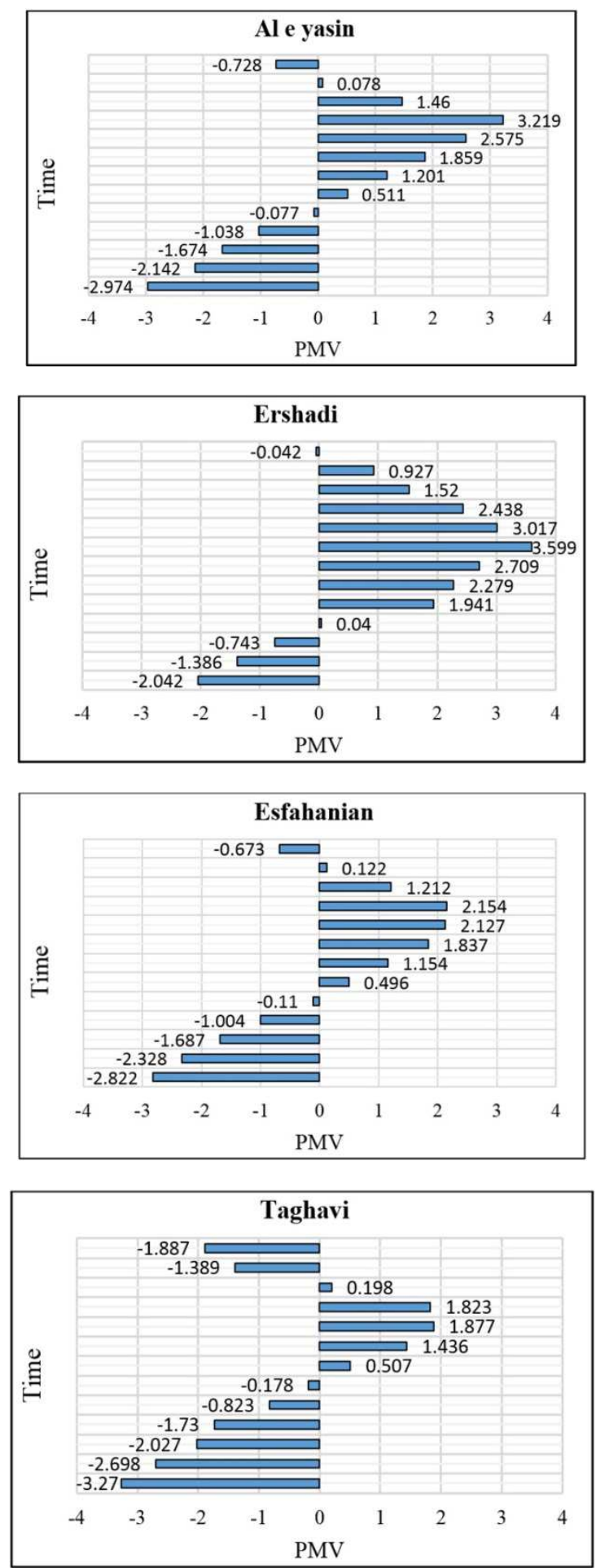

Figure 3. PMV values of Kashan and Ardabil houses in the summer.
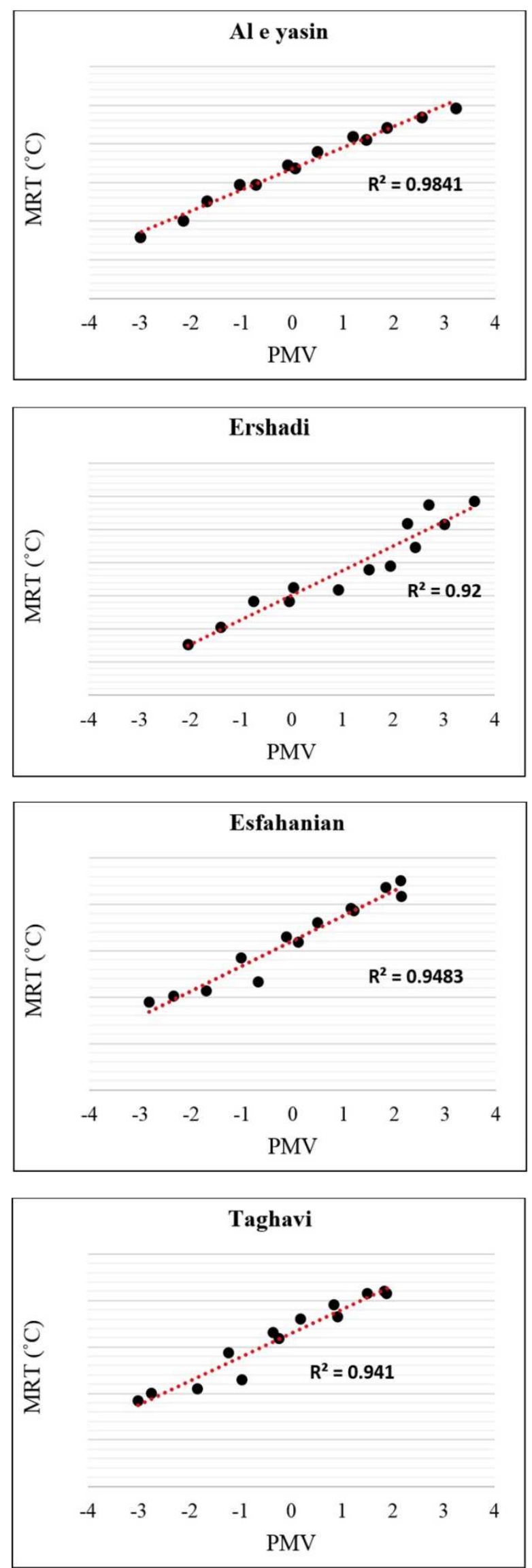

Figure 4. Correlation between Mean radiant temperature and PMV index in case studies. 
Mean radiant temperature, which sums all short wave and longwave radiation fluxes to the human body [26], is one of the most important factors that influence human thermal comfort. In Figure 4, During a day, there is a high correlation between the "mean radiant temperature" and the Predicted Mean Vote index, and reducing the "mean radiant temperature" reduces the Predicted Mean Vote index.

The calculations show that the vertical levels from the south to the southeast tend to have the best orientation in terms of receiving the sun's heat, which means that they receive the highest radiation in cold days and receive the smallest radiation in hot days. North-facing surfaces receive the lowest heat throughout the day. The westward and southwest levels have the worst direction in terms of receiving radiation from the sun, because at warmer times, they get the highest heat and, at cool times, they get less heat than other directions. The walls facing the south receive the highest amount of radiation around noon in the winter, while the walls toward the east, the morning and walls facing the west, receive the most radiation in the evening. The walls in the north are almost devoid of sunlight. So it is possible to cool the spaces in the summer, to the north. Also, the main living space is in the optimal direction, from south to south-east. It is also preferable not to be assigned to living spaces in the western frontiers and in the second eastern part.

Table 8 shows the condition of the yard with the climate and the courtyard walls in the historic houses of Ardebil and Kashan.

Table 8. Conditioning with Climates Levels Based on the Summer Shadow Coverage.

\begin{tabular}{|c|c|c|c|c|c|c|}
\hline \multirow{2}{*}{\multicolumn{2}{|c|}{ Climatic conditions of walls }} & \multicolumn{5}{|c|}{ Percent cover shadow levels in July } \\
\hline & & Courtyard & Wall 1 & Wall 2 & Wall 3 & Wall 4 \\
\hline \multirow{2}{*}{ Kashan } & Esfahanian & 41.75 & 85 & 85.8 & 100 & 86.2 \\
\hline & Al e Yasin & 26.35 & 73.3 & 87.3 & 68.5 & 71.7 \\
\hline \multirow{2}{*}{ Ardabil } & Ershadi & 35.56 & 50.1 & 63.9 & 83.7 & 76.3 \\
\hline & Taghavi & 15.98 & 59 & 57.3 & 77.3 & 74.7 \\
\hline
\end{tabular}

(25-0 inappropriate, 50-25 fairly suitable, 75-50 suitable and 100-75 very suitable).

\section{Conclusion}

By continuously controlling the shadow on the courtyard surfaces, suitable dimensions and also the direction of the building, it is possible to reduce the heat transfer of the sun to the building. In this article, the importance of shadow supply was introduced in the central courtyard of the tropical and cold tropical houses. For this purpose, the most appropriate direction and dimensions of the central courtyard were introduced using the measurement and comparison of the shadow of each sample in the months of the year. In the first place, the right shape for the yard in these areas is rectangular. The results of the studies indicate that increasing the ratio of length to width and also increasing the height of the walls of the central courtyard, the percentage of shade coverage also increases. It is also the best front in terms of receiving solar energy in the south-south-east front line, which is well-positioned yearround. The front on the north and the directions close to it is the best front in hot weather, which is the most Creates shadow levels that can be used to deploy spaces that are most commonly used in hot weather.

One of the most important finding of this paper is to achieve the optimal pattern of the central courtyard by calculating the shadow level for the courtyards of the cities of Kashan and Ardabil, and extracting an easy interface to calculate it by the amount of shadow. Overall, the evaluation process presented in this article provides architects and designers with criteria and methods that will be used in the design process to improve the quality of the yard and improve the comfort conditions and significant energy savings.

\section{References}

[1] Zinzi, M. and E. Carnielo, Impact of urban temperatures on energy performance and thermal comfort in residential buildings. The case of Rome, Italy. Energy and Buildings, 2017. 157: p. 20-29.

[2] Soflaei, F., M. Shokouhian, and W. Zhu, Socio-environmental sustainability in traditional courtyard houses of Iran and China. Renewable and Sustainable Energy Reviews, 2017. 69: p. $1147-1169$.

[3] Amasyali, K. and N. M. El-Gohary, A review of datadriven building energy consumption prediction studies. Renewable and Sustainable Energy Reviews, 2018. 81: p. 1192-1205.

[4] Akbari, H. and S. Teshnehdel, Climatic Compatibility of Courtyard Houses, Based on Shading-sunlit Index; Case Studies: Traditional Houses in Kashan \& Ardabil Cities. Armanshahr architecture \& urban development, 2018. 11 (24): p. 13.

[5] Standard55. 2018; Available from: https://www.ashrae.org/technicalresources/bookstore/standard-55-thermal-environmentalconditions-for-human-occupancy.

[6] Matzarakis, A., H. Mayer, and M. G. Iziomon, Applications of a universal thermal index: physiological equivalent temperature. International journal of biometeorology, 1999. 43 (2): p. 76-84.

[7] Muhaisen, A. S. and M. B. Gadi, Mathematical model for calculating the shaded and sunlit areas in a circular courtyard geometry. Building and environment, 2005. 40 (12): p. 16191625 . 
[8] Muhaisen, A. S. and M. B. Gadi, Shading performance of polygonal courtyard forms. Building and Environment, 2006. 41 (8): p. 1050-1059.

[9] Hassan, M. H. Ventilated Courtyard as a passive cooling strategy in the hot desert climate. in 33nd AIVC Conference "Optimising Ventilative Cooling and Airtightness for [Nearly] Zero-Energy Buildings, IAQ and Comfort", Denmark. 2012.

[10] Manioğlu, G. and G. K. Oral, Effect of courtyard shape factor on heating and cooling energy loads in hot-dry climatic zone. Energy Procedia, 2015. 78: p. 2100-2105.

[11] Ahmad, I., E. Khetrish, and S. Abughres, Thermal analysis of the architecture of old and new houses at Ghadames. Building and Environment, 1985. 20 (1): p. 39-42.

[12] MeteorologicalOrganization. Available from: http://www.irimo.ir/eng/index.php.

[13] Steemers, K., Cities, energy and comfort: a PLEA 2000 review. Energy \& Buildings, 2003. 1 (35): p. 1-2.

[14] Littlefair, P., Environmental site layout planning: solar access, microclimate and passive cooling in urban areas. 2000: BRE publications.

[15] Berkovic, S., A. Yezioro, and A. Bitan, Study of thermal comfort in courtyards in a hot arid climate. Solar Energy, 2012. 86 (5): p. 1173-1186.

[16] Ali-Toudert, F., et al., Outdoor thermal comfort in the old desert city of Beni-Isguen, Algeria. Climate research, 2005. 28 (3): p. 243-256.

[17] Oke, T. R., Boundary layer climates. 2002: Routledge.
[18] Landsberg, H. E., The urban climate. Vol. 28. 1981: Academic press.

[19] Almhafdy, A., et al., Courtyard design variants and microclimate performance. Procedia-Social and Behavioral Sciences, 2013. 101: p. 170-180.

[20] Givoni, B., Man, climate and architecture. Elsevier, 1969.

[21] Meir, I. Courtyard microclimate: A hot arid region case study. in Architecture-City-Environment. Proc. 17th PLEA Int. Conference. 2000.

[22] Tahbaz, M., Tarrahi dar faza-ye baz [Shade Design in Open Space]. Journal of Honarhaye Ziba, 2007. 13: p. 27-38.

[23] Cho, S. and N. Mohammadzadeh. Thermal comfort analysis of a traditional Iranian courtyard for the design of sustainable residential buildings. in Proceedings of 13th Conference of International Building Performance Simulation Association, Chambéry, France. 2013.

[24] Muhaisen, A. S., Shading simulation of the courtyard form in different climatic regions. Building and Environment, 2006. 41 (12): p. 1731-1741.

[25] Muhaisen, A. S. and M. B. Gadi, Effect of courtyard proportions on solar heat gain and energy requirement in the temperate climate of Rome. Building and Environment, 2006. 41 (3): p. 245-253.

[26] Thorsson, S., et al., Different methods for estimating the mean radiant temperature in an outdoor urban setting. International Journal of Climatology: A Journal of the Royal Meteorological Society, 2007. 27 (14): p. 1983-1993. 